Cite this publication as follows:

O'Kelly, B.C. and Li, W. (2018) Comparing water contents of organic soil determined on the basis of different oven-drying temperatures. In Proceedings of the China - Europe Conference on Geotechnical Engineering, 13-16th August 2018, Vienna, Austria (Wu W and Yu H-S (eds)). Springer, Cham, Switzerland, vol. 1, pp. 586-590, https://doi.org/10.1007/978$\underline{3-319-97112-4 \quad 131}$

\title{
Comparing Water Contents of Organic Soil Determined on the Basis of Different Oven-Drying Temperatures
}

\section{Brendan C. O'Kelly}

Department of Civil, Structural \& Environmental Engineering,

Trinity College Dublin, Dublin, Ireland. bokelly@tcd.ie

\section{Weichao Li}

Department of Geotechnical Engineering,

Tongji University, Shanghai, China.

Proceedings of the China - Europe Conference on Geotechnical

Engineering, Vienna, Austria, 14th August 2018. 


\section{Water content determination using oven-drying method}

Water content, $w=\frac{m_{\mathrm{w}}}{m_{\mathrm{d}}}$

$m_{\mathrm{d}}$, specimen equilibrium dry mass (dry solids mass )

$m_{\mathrm{w}}$, mass of pore water (mass of wet specimen - dry solids mass)

For mineral soils, with a few exceptions, employ standard oven-drying temperature $(t)$ ranges of:

$$
\begin{aligned}
& 105-110^{\circ} \mathrm{C}(\mathrm{BS} 1377-2) \\
& 110 \pm 5^{\circ} \mathrm{C}(\mathrm{ASTM} \text { D2216) }
\end{aligned}
$$




\section{For organic soils:}

Oven-drying for $t>80-85^{\circ} \mathrm{C}$ may cause some charring and/or oxidation of susceptible organic matter

$\Rightarrow>$ Reduction in specimen equilibrium dry mass, $\Delta m_{\mathrm{d}}$ : perceived as increase in mass of pore water

$\Rightarrow$ Over-prediction of water content value, that is:

$$
w_{\text {high }}=\frac{m_{\mathrm{w}}+\Delta m_{\mathrm{d}}}{m_{\mathrm{d}}-\Delta m_{\mathrm{d}}}
$$

For $t<100^{\circ} \mathrm{C}$, all pore water is not evaporated

$\Rightarrow>$ under-prediction of water content value occurs for $t<85^{\circ} \mathrm{C}$ (approximately) (O'Kelly, 2004, 2005b) 
Reduction in specimen equilibrium dry mass for increasing $t$ value significant for peat and other highly organic soils
$\square 1$ Silt
$\diamond 2$ Clay
$\triangle 3$ Marl-1
- 4 Marl-2
$\times 5$ Shelly marl
-6 Organic marl
$\diamond 7$ Organic clay
$\triangle 8$ Peat-1 $(\mathrm{H} 3)$
- 9 Peat-2 (H4)

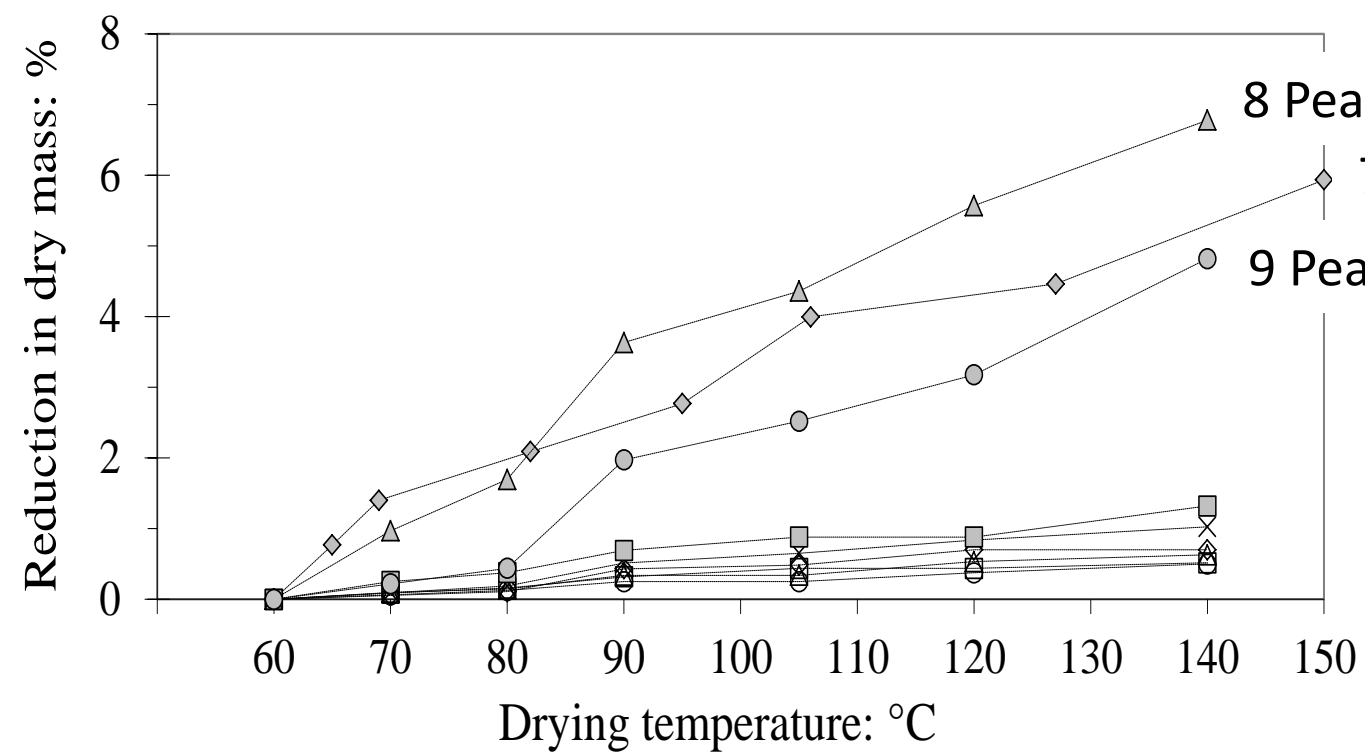

Figure 1.

All data reproduced from O'Kelly (2005a)

\begin{tabular}{|c|c|c|c|c|c|}
\hline Label & $\begin{array}{c}\text { Soil } \\
\text { type }\end{array}$ & $\begin{array}{c}\text { Liquid } \\
\text { limit } \\
(\%)\end{array}$ & $\begin{array}{c}\text { Plastic } \\
\text { limit } \\
(\%)\end{array}$ & $\begin{array}{c}\text { Particle } \\
\text { density } \\
\left(\mathrm{Mg} / \mathrm{m}^{3}\right)\end{array}$ & $\begin{array}{c}\text { Loss on } \\
\text { ignition, } N \\
(\%)\end{array}$ \\
\hline \hline 1 & Silt & 65 & 32 & 2.66 & 3.0 \\
2 & Clay & 83 & 35 & 2.70 & 5.6 \\
3 & Marl-1 & 116 & 95 & 2.22 & 6.7 \\
4 & Marl-2 & 131 & 106 & 2.41 & 6.9 \\
5 & Shelly marl & 107 & 59 & 2.35 & 10.0 \\
6 & Organic marl & 180 & 130 & 2.06 & 29.7 \\
7 & Organic clay & 315 & 53 & 1.55 & 70.0 \\
8 & Peat-1 [H3] & 900 & 310 & 1.19 & 87.7 \\
9 & Peat-2 [H4] & 735 & 485 & 1.47 & 92.9 \\
\hline
\end{tabular}




\section{Impact of adopting different $t$ values}

- For instance, in correlating undrained shear strength with water content

Figure 2. Undrained strength correlations for water-treatment residue material $(N=57 \%)$ (O'Kelly, 2014).

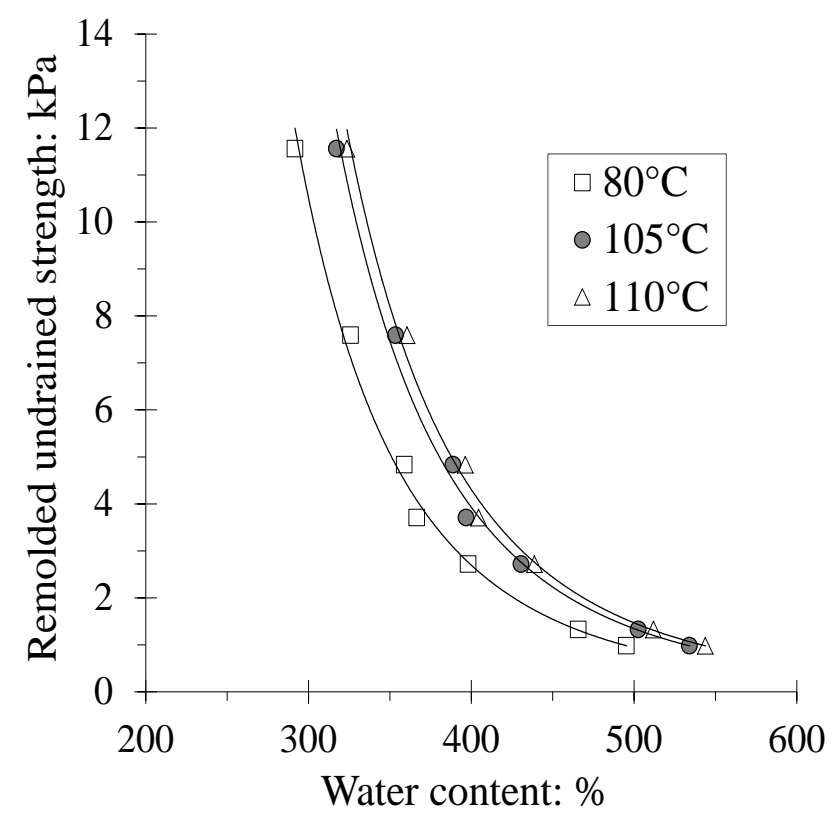

- Also effects values computed from mass - volume relationships.

As concluded in the papers by O'Kelly (2014), O'Kelly and Sivakumar (2014) and Skempton and Petley (1970):

the standard $t$ value of $105^{\circ} \mathrm{C}$ employed for inorganic soil is appropriate and preferable than using lower $t$ values in performing routine water content determinations on peat and other organic soils. 
Figure 3 shows sample data demonstrating drying behaviour of Clara Bog peat material in gravity-convection oven for step increases in $t$ value (O'Kelly and Sivakumar, 2014)

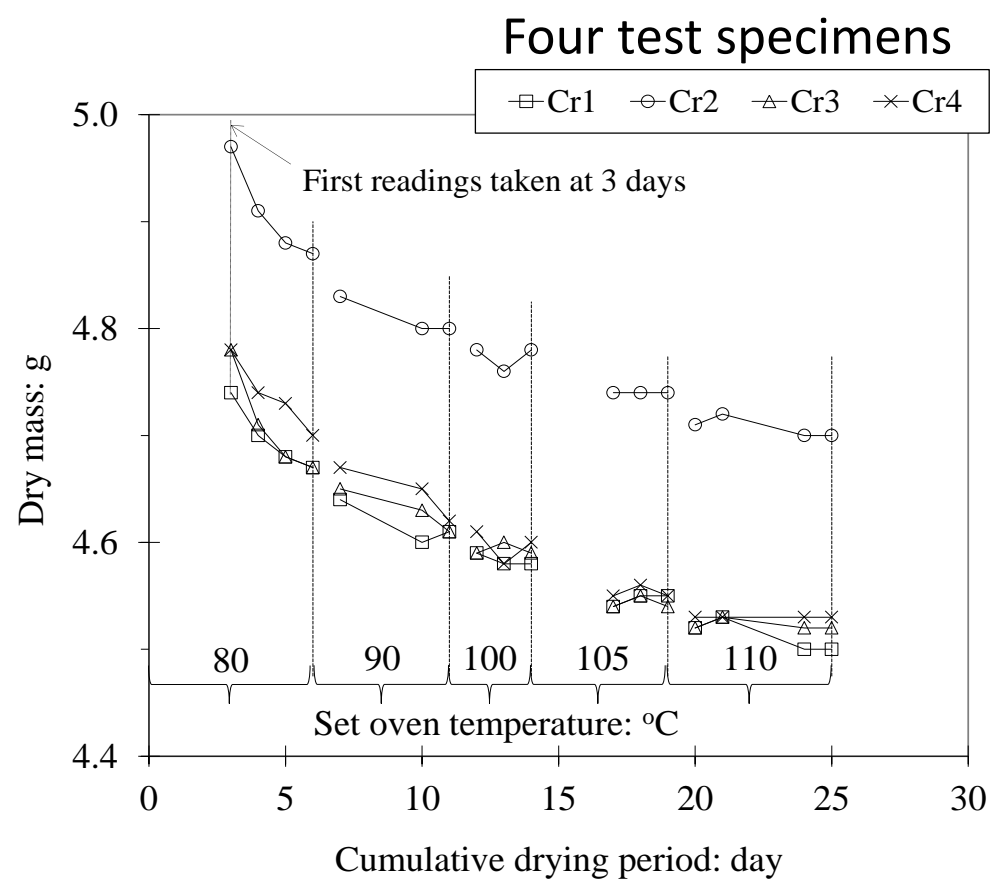

\begin{tabular}{|l|r|}
\hline Material property & Clara peat \\
\hline Water content (\%) & 1065 \\
\hline Liquid limit (\%) & 757 \\
\hline Plastic limit (\%) & 446 \\
\hline Plasticity index & 311 \\
\hline Particle density $\left(\mathrm{Mg} / \mathrm{m}^{3}\right)$ & 1.42 \\
\hline Fiber content $(\%)$ & 16.7 \\
\hline Loss on ignition, $N(\%)$ & 98.5 \\
\hline pH & 3.7 \\
\hline
\end{tabular}

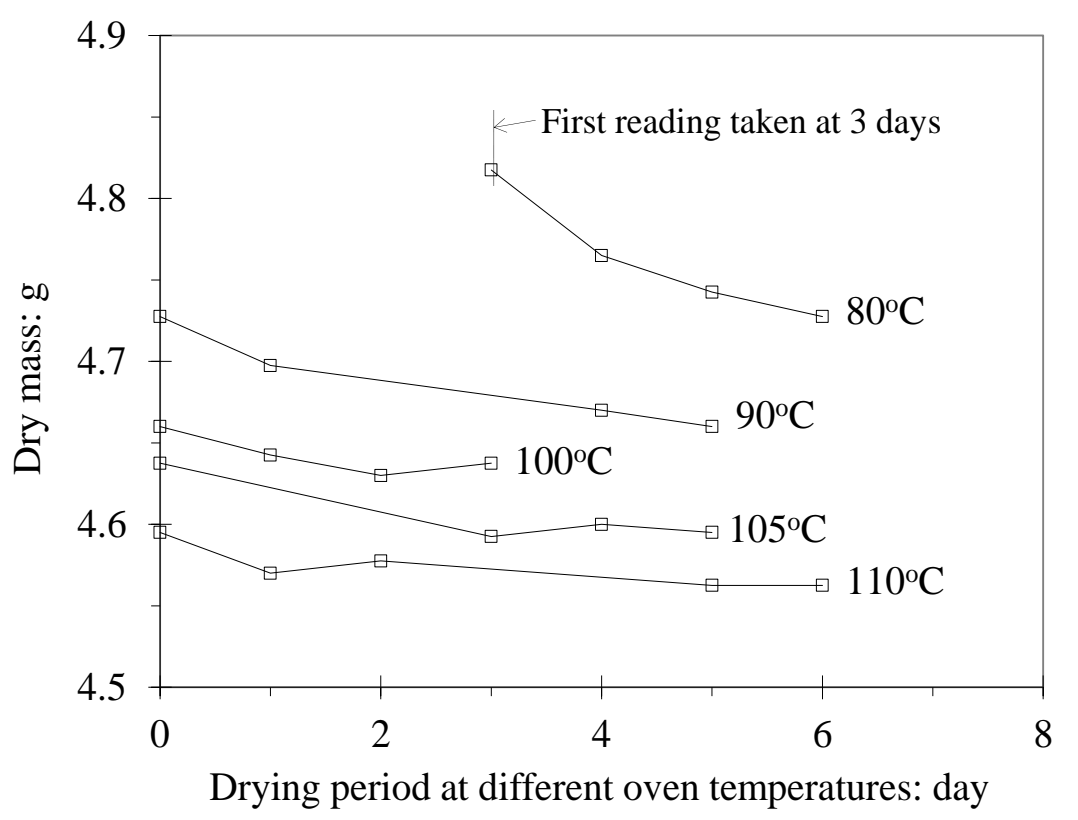

Reduction in specimen dry mass against drying period for different $t$ values 
For consistency, recommended that values of water content corresponding to standardised $t$ value of $105^{\circ} \mathrm{C}$ are deduced in cases where measured or reported water content values have been determined on the basis of lower $t$ values (O'Kelly, 2014; O'Kelly and Sivakumar, 2014).

According to the method after O'Kelly (2004, 2005a), the water content value corresponding to $t=105^{\circ} \mathrm{C}$ (i.e., $w_{105^{\circ}} \mathrm{C}$ ) can be computed from the water content value deduced for $t^{\circ} \mathrm{C}$ (i.e., $w_{t^{\circ} \mathrm{C}}$ ) according to the following expression:

$$
w_{105^{\circ} \mathrm{C}}=\left(w_{t^{\circ} \mathrm{C}}-\alpha_{105^{\circ} \mathrm{C}}+1\right) / \alpha_{105^{\circ} \mathrm{C}}
$$

where $w_{105^{\circ} \mathrm{C}}$ and $w_{t^{\circ} \mathrm{C}}$ are expressed in dimensionless form (not \% values)

and the water content parameter, $\alpha_{105^{\circ} \mathrm{C}}=m_{105^{\circ} \mathrm{C}} / m_{t^{\circ} \mathrm{C}}$

$$
\left[\alpha_{105^{\circ} \mathrm{C}} \leq 1 \text { for } t<105^{\circ} \mathrm{C}\right]
$$

where $m_{105^{\circ} \mathrm{C}}$ and $m_{t^{\circ} \mathrm{C}}$ are the specimen equilibrium dry masses corresponding to $t$ values of $105^{\circ} \mathrm{C}$ and $t^{\circ} \mathrm{C}$, respectively. 


\section{Determination of pertinent $\alpha_{105^{\circ} \mathrm{c}}$ value}

- Experimentally derived

Figure 4. $\alpha_{105^{\circ} \mathrm{C}}$ values plotted against drying temperature for Clara Bog peat material (O'Kelly and Sivakumar, 2014)

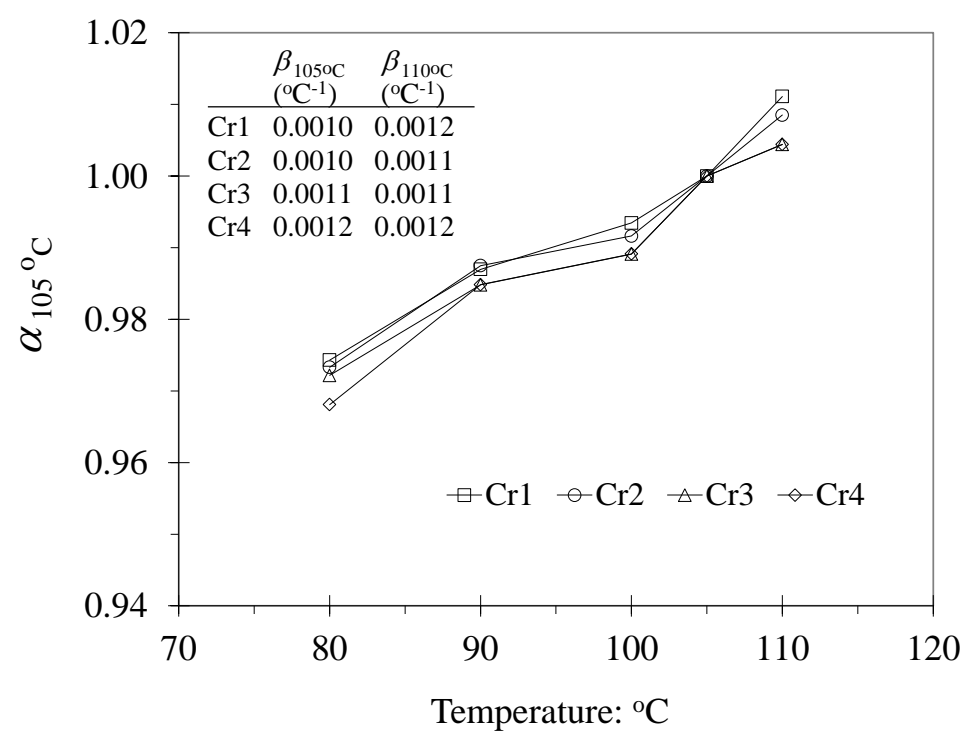

However, soil specific and time consuming exercise

- Correlation

O'Kelly and Sivakumar (2014) investigated the relationship between $N$ and the gradient of the $\alpha_{105^{\circ} \mathrm{C}}-t$ trend-line for 18 very different organic soils. 
O'Kelly and Sivakumar (2014) denoted the gradient of the best-fit line to the $\alpha_{105^{\circ} \mathrm{C}}-t$ plot for $t \leq 105^{\circ} \mathrm{C}$ as the $\beta_{105^{\circ} \mathrm{C}}$ parameter value, which they presented as a function of the $N$ value, as shown in below figure.

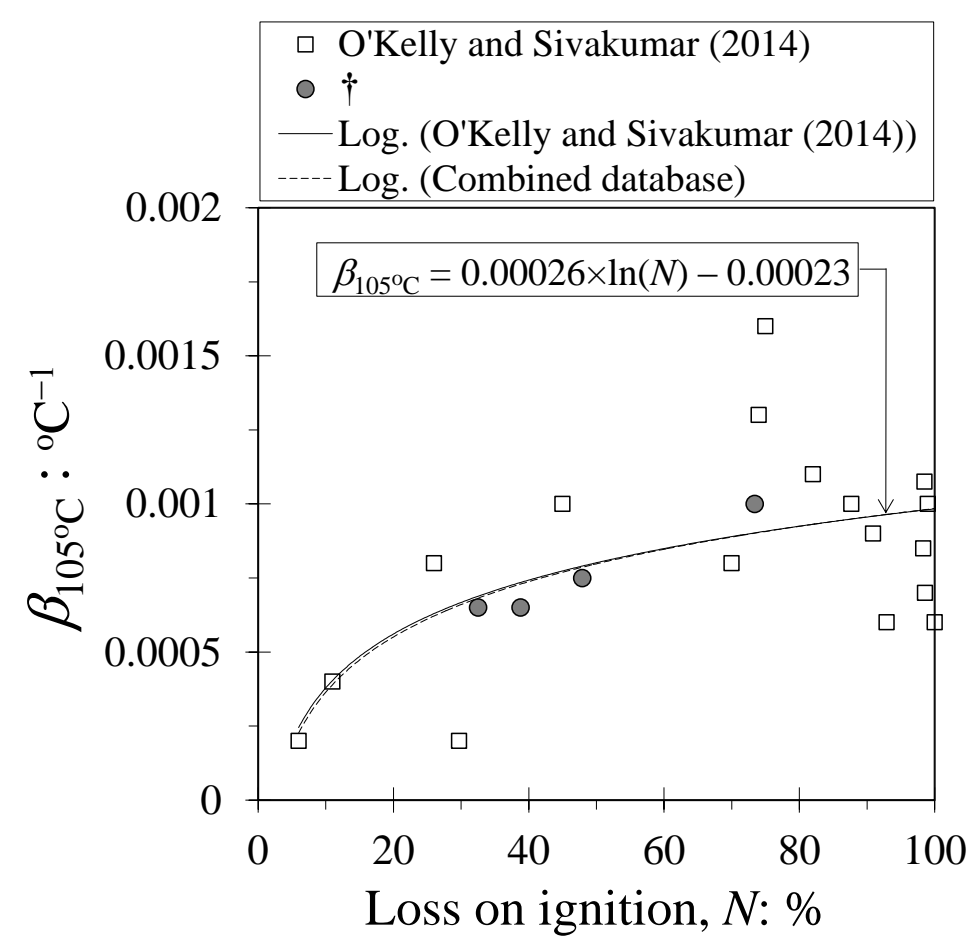

Deduced relationship given by

$\beta_{105^{\circ} \mathrm{C}}=0.00026 \times \ln (N)-0.00023$

Included in this figure are additional data from forthcoming article entitled 'Water Content Determinations for Peaty Soil Using the Oven-Drying Method' by Weichao Li et al. for four highly decomposed peaty soils ( $N=32.5-73.4 \%$ ) sampled from the northeast shore of Dianchi Lake in Kunming city, Yunnan, China. 


\section{Summary and Conclusions}

Growing consensus is that standardised $t$ value of $105^{\circ} \mathrm{C}$ used for inorganic soil is also appropriate for routine water content determinations on organic soils.

Method for computing and comparing water content values determined for different $t$ values presented.

$\beta_{105^{\circ} \mathrm{C}}$ value estimated for a specific organic soil from its measured or reported $N$ value using correlation given by Equation 5 .

Pertinent $\alpha_{105^{\circ} \mathrm{C}}$ value used for making comparisons and standardisation of water content values determined on the basis of different $t$ values estimated from deduced $\beta_{105^{\circ} \mathrm{C}}$ value and the difference in the $t$ values employed.

In other words, water content values determined for $t<105^{\circ} \mathrm{C}$ standardised to the recommended $t$ value of $105^{\circ} \mathrm{C}$ using the estimated $\alpha_{105^{\circ} \mathrm{C}}$ value and Equation 4. 


\section{$\underline{\text { References }}$}

- ASTM D2216-10: Standard test methods for laboratory determination of water (moisture) content of soil and rock by mass. ASTM International, West Conshohocken, PA, USA.

- BS1377-2: 1990. Methods of test for soils for civil engineering purposes (classification tests). BSI, London, UK.

- O'Kelly BC (2004) Accurate determination of moisture content of organic soils using the oven drying method. Drying Technology 22(7): 1767-1776, https://doi.org/10.1081/DRT-200025642

- O'Kelly BC (2005a) Method to compare water content values determined on the basis of different oven drying temperatures. Géotechnique 55(4): 329-332, https://doi.org/10.1680/geot.2005.55.4.329

- O'Kelly BC (2005b) New method to determine the true water content of organic soils. Geotechnical Testing Journal 28(4): 365-369, https://doi.org/10.1520/GTJ11963

- O'Kelly BC (2005c) Oven-drying characteristics of soils of different origins. Drying Technology 23(5): 1141-1149, https://doi.org/10.1081/DRT-200059149

- O'Kelly BC (2014) Drying temperature and water content-strength correlations. Environmental Geotechnics 1(2): 81-95, https://doi.org/10.1680/envgeo.13.00016

- O'Kelly BC and Sivakumar V (2014) Water content determinations for peat and other organic soils using the oven-drying method. Drying Technology 32(6): 631-643, https://doi.org/10.1080/07373937.2013.849728

- Skempton AW and Petley DJ (1970) Ignition loss and other properties of peats and clays from Avonmouth, King's Lynn and Cranberry Moss. Géotechnique 20(4): 343-356, https://doi.org/10.1680/geot.1970.20.4.343 